RESEARCH AND PRACTICE

\title{
A quantile regression approach to measuring the educational effect on body mass index
}

\author{
Dakshina G. De Silva, $\mathrm{PhD}^{1}$, Bradley T. Ewing, $\mathrm{PhD}^{2}$, Catherine P. Slade, $\mathrm{PhD}^{3}$, and Mark A. Thompson, $\mathrm{PhD}^{3}$ \\ ${ }^{1}$ Department of Economics, Lancaster University Management School, Lancaster, U. K., ${ }^{2}$ Rawls College of Business Texas Tech University, \\ Lubbock, TX, and ${ }^{3}$ James M. Hull College of Business, Augusta University, Augusta, GA
}

\begin{abstract}
Background: By use of a publically available database, the effects of education and geography on obesity as measured by body mass index (BMI) were evaluated with a quantile regression approach. The focus of the analysis was on the practical interpretation of the regression results to inform health policy decision makers about the importance of educational attainment for the growing public health issue of obesity in the US, particularly in the Southeast.
\end{abstract}

Methods: With data from the 2007 Behavioral Risk Factor Surveillance System (BRFSS), quantile regressions were employed to estimate the educational effect on BMI while controlling for relevant lifestyle, socioeconomic, geographic, and demographic factors.

Results: The findings indicate that education is important, for college graduates have lower BMIs, regardless of their relative weight distribution. Persons with college educations and annual incomes of more than \$50,000 had lower BMIs than those without college education and lower income. Also, after controlling for relevant lifestyle, socioeconomic, and demographic factors such as physical activity, education, and income, regional variations are evident. There are higher BMI levels in the South as compared to other regions in the US.

Conclusions: For obesity, there are underlying causes and contributing factors, such as educational attainment and the related factor, income, that are not always considered as high priorities for addressing obesity issues. The focus has typically been on lifestyle choices, such as eating habits and physical activity. The present findings promote efforts for ensuring college education for young people to address various public health issues, including obesity. Further, econometric analysis of secondary databases could lead to a better understanding for policy makers in regard to allocation of resources to address educational attainment, recognizing its effect on public health issues such as obesity.

Key Words: health policy, obesity, educational attainment, regional variation, quantitative analysis

\section{INTRODUCTION}

Obesity is an issue of growing concern. People in the US have increased in average weight since the 1950's but not necessarily in a healthy way (Costa, 2015). Obesity is linked to health problems that cost Americans $\$ 75$ billion each year (Finkelstein, Ruhm, \& Kosa, 2005). As the proportion of Americans classified as obese continues to grow (Ogden, Flegal, Carroll, \& Johnson, 2002; Ljungvall, \& Zimmerman, 2012), it becomes a priority to understand the causes and contributing factors for obesity. This information can be used to develop better and more effective federal and state policies and programs to reduce the incidence of obesity and its associated health complications.

Previous research has examined various factors and their relationship to body mass index (BMI). In general, the focus has been on lifestyle issues and how to change individual habits such as exercising and nutrition. For example, certain lifestyle factors such as unhealthy diets and physical inactivity have been linked to obesity (Lin, Huang, \& French, 2004; Chou, Grossman, \& Saffer, 2004; Zhang, \& Wang, 2004; Huffman \& Rizov, 2007; Bhattacharya, Choudhry, \& Lakdawalla, 2008; Yen, Zhuo, \& Eastwood,
2009). Obesity has also been linked to lifestyle choices, to demographics including where people live (Kirby, Liang, Chen, \&Wang, 2012; Cohen, Rehkopf, Deardoff, \& Abrams, 2013), to income, and to the interaction of various genetic and environmental risk factors (Liu, Walter, Glymour, et al., 2015). Level of education seems to relate to health knowledge, and obesity is associated with level of education (Nayga, 2000). The effects of education on obesity begin early in a child's life (Farley \& Dowell, 2014).

Many of the previous studies on obesity have focused on statistics about individuals and either their average BMIs or their particular weight category, such as normal, overweight, and obese (Yen, Chen, \& Eastwood, 2009). Although these categories are helpful for understanding individual concerns about obesity, metrics of this type may not be helpful for policy makers. In an approach for addressing the public health challenges of obesity, this problem was to consider the result of a complex network of factors and issues. A conclusion was that more sophisticated econometric analyses were needed. A recent example of methodological advancement is found in a study that utilized a "switching” regression approach to examine the 
effects of various lifestyle and socio-demographic factors on BMI by different weight categories (Mabry \& Bures, 2014; Fallah-Fini, Rahmandad, Huang, Bures, et al. 2014). This extension beyond the standard ordinary least squares regression modeling allows a test of whether the relationship between obesity and various underlying factors is constant across weight categories.

The present investigation involved quantile regressions to expand on the common analytic methodology that is typically focused on three common weight categories of obesity, i.e., normal, overweight, and obese (Yen, Chen, \& Eastwood, 2009). Quantile regressions allow an examination of the influence of a variety of factors on weight across BMI distributions instead of more subjective weight categories. This statistical approach provides a better understanding of the educational, income, and regional factors that relate to obesity.

\section{METHODS}

This study employed data obtained from the Behavioral Risk Factor Surveillance System (BRFSS) for the year 2007. This dataset has been described elsewhere (Pierannunzi, Hu, \& Balluz, 2013; CDC, 2007). Each observation in the data set is identified by a unique ID and reports the BMI; state of residence; place of residence in terms of city, urban, or rural; gender; age; income; education; race; and lifestyle characteristics of individual adults. Our interest was in examining the effect of educational differences on BMI, while controlling for lifestyle characteristics, in this case, physical activity and demographics including regional variations.

The dependent variable was the individual BMI. According to the US Department of Health \& Human Services National Heart and Lung Institute (US DHHS, 2016), the ideal BMI for an adult is within 18.5 to 24.9, regardless of gender; persons with BMIs greater than 30 are regarded as medically obese. These standards for BMI were used to analyze independent variables.

As shown in Table 1, there are two BMI specific variables. The College variable describes whether or not the respondent had a college education. The dummy variables for Income levels of respondents are divided into two groups including greater than $\$ 50,000$ per year annual income and less than $\$ 50,000$ per year annual income.

Table 1 also describes the variables used in the regression model. The metropolitan statistical area (MSA) variables categorize respondents as: 1) in the center city; 2) not in the city center but in the county of the center city; and 3) in a suburban area within the MSA. The Income variable categories include less than $\$ 15,000$ annual income, $\$ 15,000$ to less than $\$ 25,000, \$ 25,000$ to less than $\$ 35,000$, $\$ 35,000$ to less than $\$ 50,000, \$ 50,000$ to less than $\$ 75,000$, and $\$ 75,000$ or greater. Education categories include: not a high school graduate; high school graduate but no college; some college or technical school education; and college graduate. The Age variable is measured in years. Gender is measured with a dummy variable for which Males are coded 1. Two continuous variables are included to measure minutes of Moderate Physical Activity and minutes of Vigorous Physical Activity. A variable is included to indicate the County Level Average Annual Wages for Restaurant Workers using US Bureau of Labor Statistics NAICS codes (USBLS 2016). This variable is sometimes used as a proxy for eating out expenses, recognizing that frequent eating out, particularly in less expensive venues, is attributed to obesity (Binkley, Eales \& Jekanowski, 2000).

\section{Table 1. Descriptive Statistics by Region}

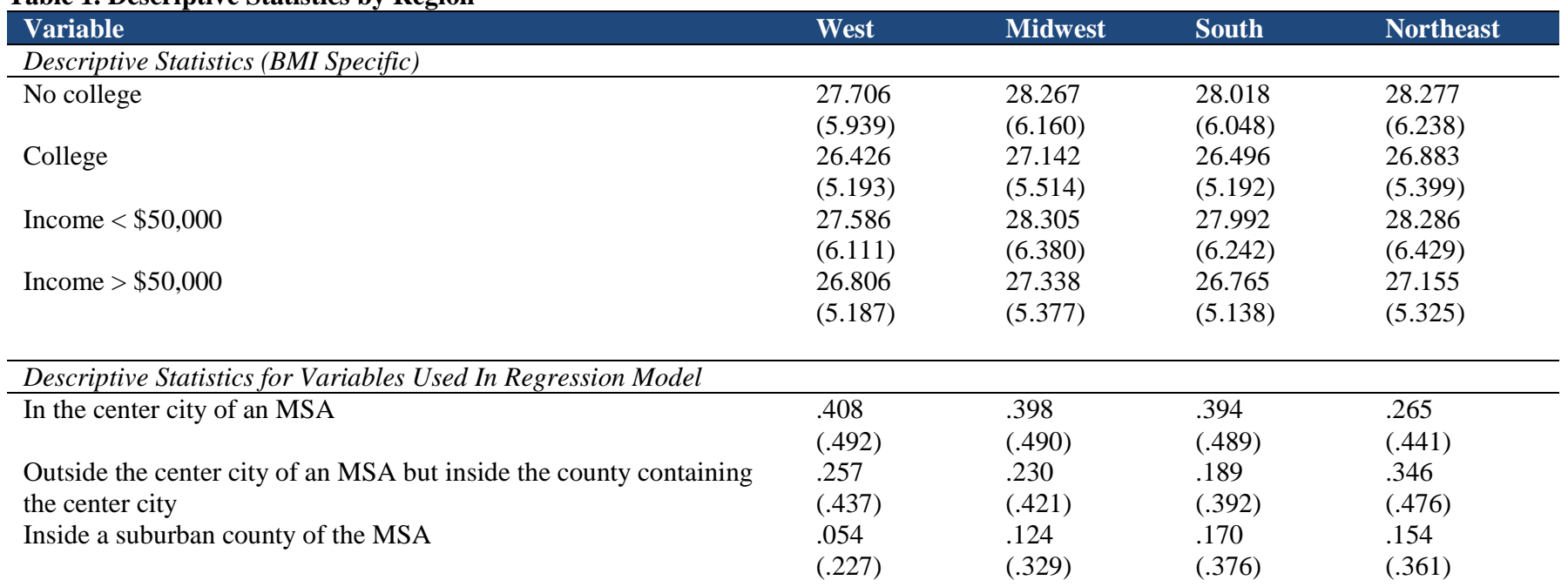


Income: less than $\$ 15,000$

Income: $\$ 15,000$ to less than $\$ 25,000$

Income: $\$ 25,000$ to less than $\$ 35,000$

Income: $\$ 35,000$ to less than $\$ 50,000$

Income: $\$ 50,000$ to less than $\$ 75,000$

Income: $\$ 75,000$ or more

Not a high school graduate

High school graduate

Some college or technical school

College graduate

Age

Male

Minutes of moderate physical activity

Minutes of vigorous physical activity

Had an alcoholic beverages in past 30 days

County level average annual wages for restaurant workers in \$ (NAICS codes: 722410, 722110-13, 722310-30)

Standard deviations are included in parentheses.

As shown Table 1, in all regions, the mean BMI is greater than 27 for persons with no college background. For all regions, the BMI drops by about 1.5 points when only people with college degrees are considered. Respondents with annual income more than $\$ 50,000$ tend to have lower BMIs relative to those with less than $\$ 50,000$ annual income.

There are significant differences in where people live by region. In the West region, 40 percent of the sample population live in the center city of an MSA; in the Northeast only 26.5 percent do so. In the Northeast, about 10 percent more live in suburbs relative to the West region. In the South, larger MSAs have an effect on where people live. People in the South are more likely than people in other regions to live in the suburban county of an MSA. Further, about half of the persons in the sample earn more than $\$ 50,000$ annually, and 35 to 41 percent are college graduates. The South has the lowest percentage of college graduates. The average age of the sample of adults is about 52.5 and about 40 percent are male. The South and the Northeast have lower percentages of males than the West and Midwest. People in the West region spend about five minutes more on moderate or vigorous physical activity compared to other regions. County-level average annual wages for restaurant workers, NAICS codes: 722410, 722110-13, 722310-30 (US BLS, 2016), which is a proxy for eating out expenses, indicate that it is cheaper to eat out

\begin{tabular}{|c|c|c|c|}
\hline .075 & .081 & .108 & .097 \\
\hline$(.264)$ & $(.273)$ & $(.310)$ & $(.297)$ \\
\hline .147 & .158 & .169 & .151 \\
\hline$(.354)$ & $(.365)$ & $(.375)$ & (.358) \\
\hline .121 & .131 & .123 & .111 \\
\hline$(.326)$ & $(.337)$ & $(.328)$ & $(.314)$ \\
\hline .172 & .169 & .158 & .149 \\
\hline$(.377)$ & $(.375)$ & $(.365)$ & $(.356)$ \\
\hline .191 & .188 & .167 & .170 \\
\hline$(.393)$ & $(.391)$ & $(.373)$ & $(.376)$ \\
\hline .295 & .273 & .275 & .322 \\
\hline$(.456)$ & $(.446)$ & $(.447)$ & $(.467)$ \\
\hline .064 & .062 & .097 & .069 \\
\hline$(.244)$ & $(.242)$ & $(.296)$ & $(.253)$ \\
\hline .246 & .299 & .284 & .283 \\
\hline$(.431)$ & $(.458)$ & $(.451)$ & $(.450)$ \\
\hline .301 & .276 & .267 & .234 \\
\hline (.459) & $(.447)$ & $(.442)$ & $(.424)$ \\
\hline .389 & .363 & .352 & .414 \\
\hline$(.488)$ & $(.481)$ & $(.478)$ & (.493) \\
\hline 52.388 & 52.753 & 53.184 & 53.662 \\
\hline (6.189) & (16.289) & (16.122) & (16.196) \\
\hline .408 & .402 & .384 & .394 \\
\hline$(.491)$ & $(.490)$ & $(.486)$ & (.489) \\
\hline 55.561 & 48.961 & 49.969 & 50.418 \\
\hline (70.391) & (63.310) & $(64.449)$ & $(64.846)$ \\
\hline 32.781 & 26.607 & 27.740 & 27.619 \\
\hline$(56.054)$ & (48.669) & $(52.460)$ & (49.523) \\
\hline .560 & .563 & .479 & .602 \\
\hline$(.496)$ & $(.496)$ & $(.500)$ & $(.490)$ \\
\hline $13,516.76$ & $11,638.07$ & $12,510.92$ & $14,369.62$ \\
\hline$(2,272.31)$ & $(2,405.161)$ & $(2,430.06)$ & $(2,814.81)$ \\
\hline
\end{tabular}

in the South and Midwest compared to the Northeast and West.

Unconditional Kernel density graphs show that BMI values are higher in the Midwest and South compared to the West and Northeast and, consistent with summary statistics presented in Table 1, persons with a college education and an income more than $\$ 50,000$ have lower BMIs (data not presented). However, caution is necessary in interpreting such observations, for, in this graphic exercise, there were no controls for differences in region, residence location, income, level of education, age, level of physical activity, or life style characteristics used in the regression models described below.

The regression modeling results were used to describe more fully the differences in BMIs by region and education levels. To account for potential heteroscedasticity in BMI values, the log of BMI was used as the dependent variable (i.e., logarithmic transformation). There were two sets of regression models. The first set used ordinary least squares (OLS); the other employed quantile regression, a technique first introduced in 1978 (Koenker, 2005). This latter method allows an estimation of the effect of education and income on the distribution of BMIs (as opposed to only the conditional mean via OLS), while taking into account other factors that contribute to the variability of BMIs. 


\section{RESULTS}

A primary interest was in examining the differences in BMIs due to income and education, as these two variables are often linked (Cohen, Rehkopf, Deardoff, Abrams, 2013; McLaren, 2007), while controlling for regional and lifestyle differences. For this, quantile regression analysis was used, as previously discussed. The basic structure of the regression model is as follows:

$$
y_{i r}=\alpha_{r}+E \mathrm{~B}+M \Gamma+X \mathrm{Z}+\mathrm{C} \Phi+\varepsilon_{i r^{*}}
$$

The dependent variable is log of BMI. The independent variables include four sets of controls: E's are controls for educational attainment, $M$ 's are controls for level of income, $X$ 's are controls for individual characteristics, and $C$ 's are controls for county characteristics.

Table 2 presents the first set of regression results. Column 1 (the income model) indicates that as income increases, persons tend to be less obese as indicated by BMIs. Column 2 (the education model) indicates that individuals with college degrees have lower BMIs compared to those with other educational backgrounds. As people age, their BMIs increase and males tend to have higher BMIs relative to females. Those who engage in physical activity and consume alcoholic beverages (at least one per month) tend to have lower BMIs. Also, people living in inner cities have lower BMIs. Further, as the county-level average wages for restaurant workers increase, in other words, when dining out is more expensive, people tend to have lower BMIs, results that are consistent with previous findings (Bhattacharya, Choudry, \& Lakdawalla, 2008). These OLS results also indicate that, in general, there are no strong regional differences in BMIs. However, care should be taken in interpreting results Column 3 (the combined education/income model), since level of education and income could be highly correlated. However, a check for correlation found that there was enough variability between the income and education variables to include them.

\begin{tabular}{|c|c|c|c|}
\hline Variable & (1) & $(2)$ & (3) \\
\hline Income: $\$ 15,000$ to less than $\$ 25,000$ & $\begin{array}{l}-.011 * * * \\
(.002)\end{array}$ & & $\begin{array}{l}-.011^{* * *} \\
(.002)\end{array}$ \\
\hline Income: $\$ 25,000$ to less than $\$ 35,000$ & $\begin{array}{l}-.011^{* *} \\
(.002)\end{array}$ & & $\begin{array}{l}-.009 * * \\
(.002)\end{array}$ \\
\hline Income: $\$ 35,000$ to less than $\$ 50,000$ & $\begin{array}{l}-.006 * * * \\
(.002)\end{array}$ & & $\begin{array}{l}-.002 \\
(.002)\end{array}$ \\
\hline Income: $\$ 50,000$ to less than $\$ 75,000$ & $\begin{array}{l}-.008 \\
(.002)\end{array}$ & & $\begin{array}{l}-.001 \\
(.002)\end{array}$ \\
\hline Income: $\$ 75,000$ or more & $\begin{array}{l}-.022 * * * \\
(.002)\end{array}$ & & $\begin{array}{l}-.012^{* * * *} \\
(.002)\end{array}$ \\
\hline High school graduate & & $\begin{array}{l}.002 \\
(.002)\end{array}$ & $\begin{array}{l}.003 \\
(.002)\end{array}$ \\
\hline Some college or technical school & & $\begin{array}{l}.007 * * * \\
(.002)\end{array}$ & $\begin{array}{l}.007 * * * \\
(.002)\end{array}$ \\
\hline College graduate & & $\begin{array}{l}-.022 * * * \\
(.002)\end{array}$ & $\begin{array}{l}-.021^{* * *} \\
(.002)\end{array}$ \\
\hline Log of Age & $\begin{array}{l}-.000 \\
(.001)\end{array}$ & $\begin{array}{l}.001 \\
(.001)\end{array}$ & $\begin{array}{l}.001 \\
(.001)\end{array}$ \\
\hline Male & $\begin{array}{l}.049 * * * \\
(.001)\end{array}$ & $\begin{array}{l}.049 * * * \\
(.001)\end{array}$ & $\begin{array}{l}.049 * * * \\
(.001)\end{array}$ \\
\hline Minutes of moderate physical activity & $\begin{array}{l}-.007 * * * \\
.000\end{array}$ & $\begin{array}{l}-.007 * * * \\
.000\end{array}$ & $\begin{array}{l}-.007^{* * *} \\
.000\end{array}$ \\
\hline Minutes of vigorous physical activity & $\begin{array}{l}-.011^{* * *} \\
.000\end{array}$ & $\begin{array}{l}-.010^{* * *} \\
.000\end{array}$ & $\begin{array}{l}-.010^{* * *} \\
.000\end{array}$ \\
\hline Had an alcoholic beverages in past 30 days & $\begin{array}{l}-.030 * * * \\
(.001)\end{array}$ & $\begin{array}{l}-.029 * * * \\
(.001)\end{array}$ & $\begin{array}{l}-.028 * * * \\
(.001)\end{array}$ \\
\hline $\begin{array}{l}\text { County level average annual wages for restaurant workers in } \$ \\
\text { (NAICS codes: } 722410,722110-13,722310-30 \text { ) }\end{array}$ & $\begin{array}{l}-.060 * * * \\
(.003)\end{array}$ & $\begin{array}{l}-.056 * * * \\
(.003)\end{array}$ & $\begin{array}{l}-.055^{* * *} \\
(.003)\end{array}$ \\
\hline In the center city of an MSA & $\begin{array}{l}-.006 * * * \\
(.001)\end{array}$ & $\begin{array}{l}-.005^{* * *} \\
(.001)\end{array}$ & $\begin{array}{l}-.005^{* * *} \\
(.001)\end{array}$ \\
\hline $\begin{array}{l}\text { Outside the center city of an MSA but inside the county containing } \\
\text { the center city }\end{array}$ & $\begin{array}{l}.000 \\
(.001)\end{array}$ & $\begin{array}{l}.001 \\
(.001)\end{array}$ & $\begin{array}{l}.000 \\
(.001)\end{array}$ \\
\hline Inside a suburban county of the MSA & $\begin{array}{l}-.001 \\
(.001)\end{array}$ & $\begin{array}{l}-.001 \\
(.001)\end{array}$ & $\begin{array}{l}-.001 \\
(.001)\end{array}$ \\
\hline Midwest & $\begin{array}{l}.005 \\
(.005)\end{array}$ & $\begin{array}{l}.008 \\
(.005)\end{array}$ & $\begin{array}{l}.008 \\
(.005)\end{array}$ \\
\hline South & $\begin{array}{l}.007 \\
(.005)\end{array}$ & $\begin{array}{l}.010^{* *} \\
(.005)\end{array}$ & $\begin{array}{l}.010^{* *} \\
(.005)\end{array}$ \\
\hline Northeast & $\begin{array}{l}.001 \\
(.005)\end{array}$ & $\begin{array}{l}.002 \\
(.005)\end{array}$ & $\begin{array}{l}.002 \\
(.005)\end{array}$ \\
\hline Race effects & Yes & Yes & Yes \\
\hline State effects & Yes & Yes & Yes \\
\hline
\end{tabular}




\begin{tabular}{llll}
\hline Variable & (1) & (2) & (3) \\
\hline Number of Obs. & 261287 & 261287 & 261287 \\
Adj $R^{2}$ & .064 & .067 & .067 \\
\hline
\end{tabular}

Standard errors are in parentheses. $* * *$ denotes statistical significance at the one percent level, $* *$ denotes statistical significance at the five percent level, and * denotes statistical significance at the 10 percent level. Robust clustered standard errors are in parentheses.

How BMI differs across distributions due to education and income while controlling for regional heterogeneities, was examined. In this case, OLS did not provide a clear picture of the distributional differences. Most previous studies have mostly based their findings on the 'average' worker or individual result; however, these findings may not be applicable to individuals at the extremes of the BMI distribution. Table 3 presents a quantile regression approach and results for the combined 'education/income model' (e.g., Column 3 in Table 2), which includes both income and education level dummies.

Table 3: Quantile Regression Results for Log of Body Mass Index with State Effects

\begin{tabular}{|c|c|c|c|c|c|}
\hline \multirow[t]{2}{*}{ Variable } & \multicolumn{5}{|l|}{ Quantile } \\
\hline & .10 & .25 & .50 & .75 & .90 \\
\hline Income: $\$ 15,000$ to less than $\$ 25,000$ & $\begin{array}{l}.010 * * * \\
(.002)\end{array}$ & $\begin{array}{l}-.001 \\
(.002)\end{array}$ & $\begin{array}{l}-.010 * * * \\
(.002)\end{array}$ & $\begin{array}{l}-.020 * * * \\
(.002)\end{array}$ & $\begin{array}{l}-.035 * * * \\
(.003)\end{array}$ \\
\hline Income: $\$ 25,000$ to less than $\$ 35,000$ & $\begin{array}{l}.022^{* * * *} \\
(.002)\end{array}$ & $\begin{array}{l}.008 * * * \\
(.002)\end{array}$ & $\begin{array}{l}-.006^{* *} \\
(.002)\end{array}$ & $\begin{array}{l}-.025^{* * *} \\
(.002)\end{array}$ & $\begin{array}{l}-.044^{* * *} \\
(.003)\end{array}$ \\
\hline Income: $\$ 35,000$ to less than $\$ 50,000$ & $\begin{array}{l}.033^{* * * *} \\
(.002)\end{array}$ & $\begin{array}{l}.017^{* * *} \\
(.002)\end{array}$ & $\begin{array}{l}-.001 \\
(.002)\end{array}$ & $\begin{array}{l}-.019 * * * \\
(.002)\end{array}$ & $\begin{array}{l}-.041^{* * *} \\
(.003)\end{array}$ \\
\hline Income: $\$ 50,000$ to less than $\$ 75,000$ & $\begin{array}{l}.041^{* * *} \\
(.002)\end{array}$ & $\begin{array}{l}.023 * * * \\
(.002)\end{array}$ & $\begin{array}{l}.002 \\
(.002)\end{array}$ & $\begin{array}{l}-.019 * * * \\
(.002)\end{array}$ & $\begin{array}{l}-.048^{* * *} \\
(.003)\end{array}$ \\
\hline Income: $\$ 75,000$ or more & $\begin{array}{l}.042 * * * \\
(.002)\end{array}$ & $\begin{array}{l}.023^{* * *} \\
(.002)\end{array}$ & $\begin{array}{l}-.006^{* *} \\
(.002)\end{array}$ & $\begin{array}{l}-.033 * * * \\
(.002)\end{array}$ & $\begin{array}{l}-.066^{* * *} \\
(.003)\end{array}$ \\
\hline High school graduate & $\begin{array}{l}.008 * * * \\
(.002)\end{array}$ & $\begin{array}{l}.006 * * \\
(.002)\end{array}$ & $\begin{array}{l}.001 \\
(.002)\end{array}$ & $\begin{array}{l}.001 \\
(.002)\end{array}$ & $\begin{array}{l}.004 \\
(.003)\end{array}$ \\
\hline Some college or technical school & $\begin{array}{l}.008 * * * \\
(.002)\end{array}$ & $\begin{array}{l}.005^{* *} \\
(.002)\end{array}$ & $\begin{array}{l}.003 \\
(.002)\end{array}$ & $\begin{array}{l}.005^{* *} \\
(.002)\end{array}$ & $\begin{array}{l}.014 * * * \\
(.003)\end{array}$ \\
\hline College graduate & $\begin{array}{l}-.010^{* * *} \\
(.002)\end{array}$ & $\begin{array}{l}-.020^{* * *} \\
(.002)\end{array}$ & $\begin{array}{l}-.027^{* *} \\
(.002)\end{array}$ & $\begin{array}{l}-.026^{* *} \\
(.002)\end{array}$ & $\begin{array}{l}-.021^{* * *} \\
(.003)\end{array}$ \\
\hline Log of Age & $\begin{array}{l}.043^{* * * *} \\
(.002)\end{array}$ & $\begin{array}{l}.036 * * * \\
(.001)\end{array}$ & $\begin{array}{l}.013^{* * *} \\
(.001)\end{array}$ & $\begin{array}{l}-.029 * * * \\
(.002)\end{array}$ & $\begin{array}{l}-.075^{* * *} \\
(.002)\end{array}$ \\
\hline Male & $\begin{array}{l}.088 * * * \\
(.001)\end{array}$ & $\begin{array}{l}.079 * * * \\
(.001)\end{array}$ & $\begin{array}{l}.059 * * * \\
(.001)\end{array}$ & $\begin{array}{l}.034^{* * * *} \\
(.001)\end{array}$ & $\begin{array}{l}.013^{* * *} \\
(.001)\end{array}$ \\
\hline Minutes of moderate physical activity & $\begin{array}{l}-.001^{*} \\
(.000)\end{array}$ & $\begin{array}{l}-.003^{* * *} \\
(.000)\end{array}$ & $\begin{array}{l}-.006^{* * *} \\
(.000)\end{array}$ & $\begin{array}{l}-.010^{* * *} \\
(.000)\end{array}$ & $\begin{array}{l}-.015^{* * *} \\
(.001)\end{array}$ \\
\hline Minutes of vigorous physical activity & $\begin{array}{l}-.003^{* * *} \\
(.000)\end{array}$ & $\begin{array}{l}-.006 * * * \\
(.000)\end{array}$ & $\begin{array}{l}-.010^{* * *} \\
(.000)\end{array}$ & $\begin{array}{l}-.014 * * * \\
(.000)\end{array}$ & $\begin{array}{l}-.017 * * * \\
(.000)\end{array}$ \\
\hline Had an alcoholic beverages in past 30 days & $\begin{array}{l}-.006^{* * *} \\
(.001)\end{array}$ & $\begin{array}{l}-.015^{* * *} \\
(.001)\end{array}$ & $\begin{array}{l}-.027^{* * *} \\
(.001)\end{array}$ & $\begin{array}{l}-.039 * * * \\
(.001)\end{array}$ & $\begin{array}{l}-.051^{* * *} \\
(.002)\end{array}$ \\
\hline $\begin{array}{l}\text { County level average annual wages for restaurant workers in \$ } \\
\text { (NAICS codes: } 722410,722110-13,722310-30 \text { ) }\end{array}$ & $\begin{array}{l}-.045^{* * *} \\
(.004)\end{array}$ & $\begin{array}{l}-.053^{* * *} \\
(.003)\end{array}$ & $\begin{array}{l}-.057 * * * \\
(.003)\end{array}$ & $\begin{array}{l}-.063^{* * *} \\
(.004)\end{array}$ & $\begin{array}{l}-.061^{* * *} \\
(.005)\end{array}$ \\
\hline In the center city of an MSA & $\begin{array}{l}-.006^{* * *} \\
(.002)\end{array}$ & $\begin{array}{l}-.005^{* * *} \\
(.001)\end{array}$ & $\begin{array}{l}-.004^{* * *} \\
(.001)\end{array}$ & $\begin{array}{l}-.005^{* * *} \\
(.002)\end{array}$ & $\begin{array}{l}-.003 \\
(.002)\end{array}$ \\
\hline $\begin{array}{l}\text { Outside the center city of an MSA but inside the county } \\
\text { containing the center city }\end{array}$ & $\begin{array}{l}.001 \\
(.002)\end{array}$ & $\begin{array}{l}.002 \\
(.001)\end{array}$ & $\begin{array}{l}.001 \\
(.001)\end{array}$ & $\begin{array}{l}.002 \\
(.002)\end{array}$ & $\begin{array}{l}.002 \\
(.002)\end{array}$ \\
\hline Inside a suburban county of the MSA & $\begin{array}{l}.001 \\
(.002)\end{array}$ & $\begin{array}{l}.001 \\
(.002)\end{array}$ & $\begin{array}{l}-.000 \\
(.002)\end{array}$ & $\begin{array}{l}-.003 \\
(.002)\end{array}$ & $\begin{array}{l}.002 \\
(.003)\end{array}$ \\
\hline Midwest & $\begin{array}{l}.018^{* *} \\
(.008)\end{array}$ & $\begin{array}{l}.023^{* *} \\
(.007)\end{array}$ & $\begin{array}{l}.015^{* * *} \\
(.007)\end{array}$ & $\begin{array}{l}.023^{* * *} \\
(.008)\end{array}$ & $\begin{array}{l}.032 * * \\
(.011)\end{array}$ \\
\hline South & $\begin{array}{l}.012 \\
(.007)\end{array}$ & $\begin{array}{l}.020 * * \\
(.005)\end{array}$ & $\begin{array}{l}.023 * * \\
(.006)\end{array}$ & $\begin{array}{l}.025 * * * \\
(.007)\end{array}$ & $\begin{array}{l}.028 * * \\
(.009)\end{array}$ \\
\hline Northeast & $\begin{array}{l}.016 * * \\
(.007)\end{array}$ & $\begin{array}{l}.012^{* *} \\
(.006)\end{array}$ & $\begin{array}{l}.006 \\
(.006)\end{array}$ & $\begin{array}{l}.016^{* *} \\
(.007)\end{array}$ & $\begin{array}{l}.020 * * \\
(.010)\end{array}$ \\
\hline Race effects & Yes & Yes & Yes & Yes & Yes \\
\hline State effects & Yes & Yes & Yes & Yes & Yes \\
\hline $\begin{array}{l}\text { Number of Obs. } \\
\text { Pseudo } R^{2}\end{array}$ & $\begin{array}{l}261287 \\
.050\end{array}$ & $\begin{array}{l}261287 \\
.048\end{array}$ & $\begin{array}{l}261287 \\
.041\end{array}$ & $\begin{array}{l}261287 \\
.048\end{array}$ & $\begin{array}{l}261287 \\
.065\end{array}$ \\
\hline
\end{tabular}

Standard errors are in parentheses. $* * *$ denotes statistical significance at the one percent level, ** denotes statistical significance at the five percent level, and * denotes statistical significance at the 10 percent level.

In the lower tail of the distribution, as income increases, BMI increases, and, in the upper tail, as income increases,
BMI declines. Further, BMI monotonically declines as income increases. For example, consider persons earning 
more than $\$ 75,000$. At the $10^{\text {th }}$ percentile, the BMI is higher by about 4.2 percent, but, at the $90^{\text {th }}$ percentile, BMI is lower by about 6.6 percent compared to persons earning less than $\$ 15,000$. This shows the effects of income on BMI. The effect is positive and significant at the lower end $\left(10^{\text {th }}\right.$ percentile) and negative and significant at the upper end of the distribution ( $90^{\text {th }}$ percentile). This finding may explain some of the mixed results of previous studies in that the income effect depends on the relative BMI distribution, which is different from results from the average of individuals in the sample.

In regard to age, on the lower tail of the BMI distribution, BMI is higher for older people. However, on the upper tail of the BMI distribution, as age increases, BMI declines. The other variables show basic patterns similar to those observed in the standard OLS results. Finally, there appears to be regional or geographical variation, for, as compared to people in the West, those in Northeast, Midwest, and South have higher BMIs.
The R2 for each model is small (about 0.05), suggesting a small effect of the education and income variables on BMI. However, there are two reasons that these effects are valid. First, small effect sizes are not atypical for analyses of social science and public health issues, for which many variables are involved in explaining any single outcome. Second, the purpose of the present report was to focus on education, income, and region, for these are less studied and are potential predictors of obesity. The purpose was not to provide prediction or causation explanations (Prentice \& Miller, 1992).

Since our main interest was to examine the effects of level of education on BMI using the quantile regression approach, a graphical representation is helpful. Figure 1 shows BMIs for varying levels of education, conditioned on the controls in Table 3. Controlling for a variety of factors, college graduates have a BMI at least 1 unit lower than persons with other levels of education. These results are qualitatively similar to results presented in Table 3 . In general, collegeeducated people consistently have lower BMI than those with less education.

Figure 1: Effects of Education on Body Mass Index
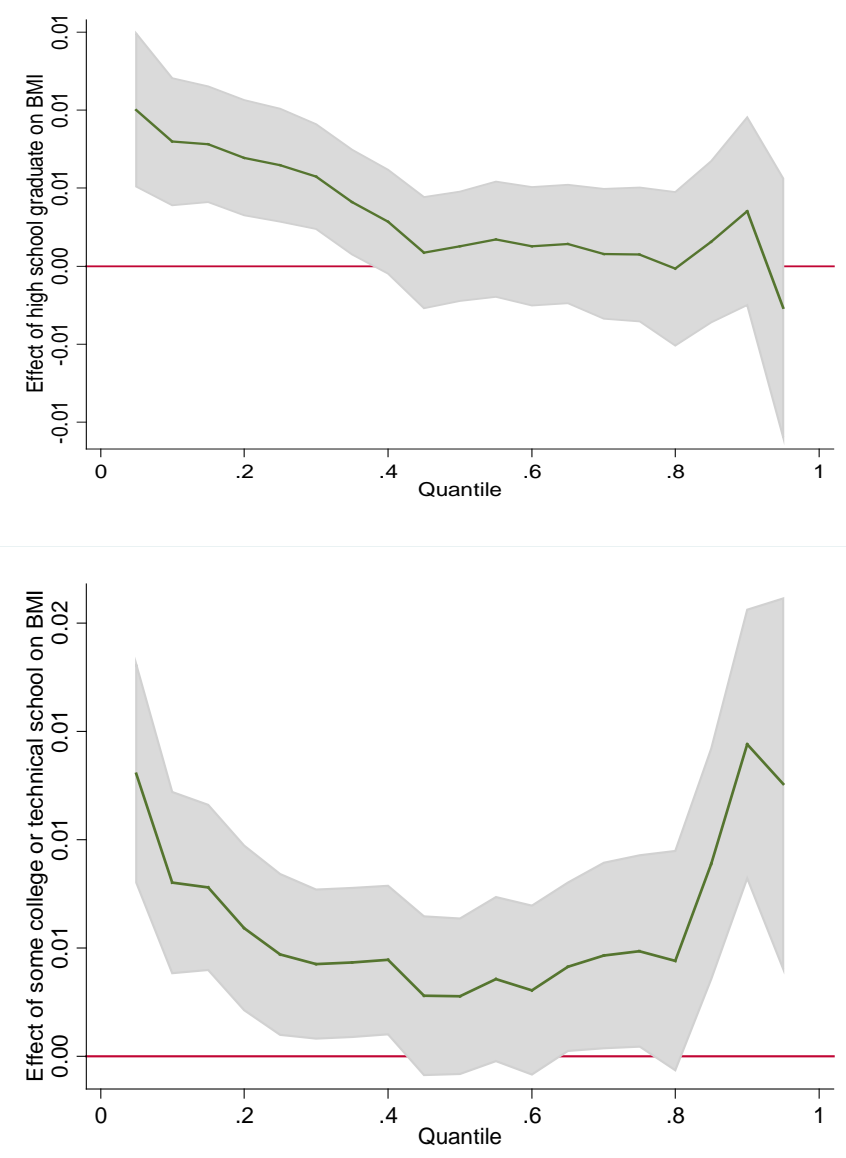


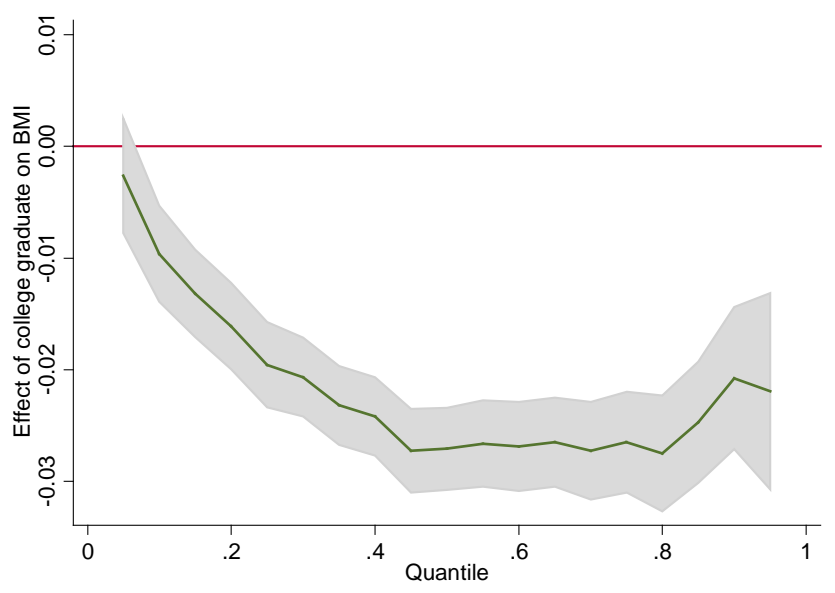

\section{DISCUSSION}

The present report extends previous work regarding factors influencing BMI by employing quantile regression analyses to investigate the effects of education and income on BMI across different distributions, with particular emphasis on the region in which an individual resides. The use of quantile regression provides insights as to how various factors may have a differential impact on BMIs, depending on the quantile that is being examined. Regardless of the method used and the control factors included, college education is associated with a lower BMI. Simply, collegeeducated people have lower BMIs than individuals with otherwise similar characteristics. This analysis can support efforts to address childhood obesity, particularly at the state policy level where there are focused efforts to encourage higher education (Eyler, Nguyen, Jooyang, Yan, \& Brownson, 2012).

The findings regarding income and region may be used to promote a greater degree of integration and coordination between health and other public policies (e.g., such as those dealing with educational attainment). For instance, an implication of the findings is that education policy may have positive spillover effects into health benefits for the general population. Thus, public programs geared towards improving societal welfare may be more cost-effective if they take into account these externalities when designing, implementing, and financing programs. In one sense, these results suggest a more coordinated and transparent process for policy design in which benefits from implementation of one program (e.g., a jobs policy that provides college tuition reimbursement or tax incentives to businesses for providing assistance with education expenses) are recognized and integrated into a health policy aimed at reducing obesity and the related problems of, for example, employee absenteeism, reduced worker productivity, and the high cost of insurance premiums. However, since there are no detailed comparison between people in different regions, the observations regarding regional differences should be examined further.

The present report adds to the literature on the relationship between socio-demographic variables and obesity. Obesity is a complex and growing public health problem in the US and, in particular, Georgia, as reflected in the low scores for residents of this state on health risk behaviors and conditions, chronic diseases, and health impairments associated with obesity ( $\mathrm{Li}$ et al. 2011). Although this is not a new public health concern, social scientists and policy makers are recognizing the increasing costs of obesity for the U.S. health care system and the importance of better understanding the underlying contributors to obesity. Analyzing this issue in more sophisticated and incremental ways creates opportunities for design and implementation of new public health programs. The results presented here link health program design to public policy concerns, such as educational attainment. This should become part of research on the relationship between education and obesity.

A conclusion is that educational attainment is reflected in BMI values, even after controlling for various lifestyle factors and regional variations. The results document that being a college graduate has a negative and significant impact on BMI across the entire distribution. Our findings can lead to development of better programs for reducing obesity rates with an emphasis on educational attainment regardless of income, lifestyle, or regional factors. This is relevant given the Georgia "Complete College Georgia" initiative (Complete College Georgia, 2012), which has the expectation that the future economy of the state will be largely based on jobs requiring some college education. Analysis of the potential spillover effects of Complete College Georgia to health outcomes is a subject for research.

\section{Acknowledgements}

The authors gratefully acknowledge Jaison Majzer, graduate assistant at the James M. Hull College of Business, Augusta University (formerly Georgia Regents University), for his assistance with manuscript formatting, preparation, and submission.

\section{References}

Bhattacharya, J., Choudhry, K., \& Lakdawalla, D. (2008). Chronic disease and severe disability among working-age population. Medical Care, 46, 92-100.

Binkley, J. K., Eales, J., \& Jekanowski, M. (2000). The relation between dietary change and rising US obesity. International Journal Of Obesity And Related Metabolic Disorders: Journal 
Of The International Association For The Study Of Obesity, 24(8), 1032-1039.

Centers for Disease Control, Behavioral Risk Factor Surveillance System. (2007). SMART-BRFSS City and County Data (2008Lincoln, NE Metropolitan Statistical Area) [Data file]. Retrieved from http://apps.nccd.cdc.gov/BRFSSSMART/SelQuestion.asp?MMSA=48\&yr2=2007\&VarRepost $=$ \&cat. Accessed October 25, 2015.

Chou, S., Grossman, M., \& Saffer, H. (2004). An economic analysis of adult obesity: results from the Behavioral Risk Factor Surveillance System. Journal of Health Economics, 23, 565-587.

Cohen, A. K., Rehkopf, D. H., Deardorff, J., \& Abrams, B. (2013). Education and obesity at age 40 among American adults. Social Science \& Medicine, 78, 34-41. doi:10.1016/j.socscimed.2012.11.025.

Complete College Georgia: Georgia’s Higher Education Completion Plan. (2012). Retrieved from http://www.usg.edu/educational_access/documents/GaHig herEducationCompletionPlan2012.pdf. Accessed January 5, 2016.

Costa, D. (2015). Health and the Economy in the United States from 1750 to the Present. Journal of Economic Literature, 53(3), 503-570.

Cutler, D., Glaeser, E., \& Shapiro, J. (2003). Why have Americans become more obese? Journal of Economic Perspectives, 17, 93118.

Eyler, A. A., Nguyen, L., Jooyoung, K., Yan, Y., \& Brownson, R. (2012). Patterns and Predictors of Enactment of State Childhood Obesity Legislation in the United States: 2006-2009. American Journal of Public Health, 102(12), 2294-2302, doi:10.2105/AJPH.2012.300763

Fallah-Fini, S., Rahmandad, H., Huang, T. T., Bures, R. M., \& Glass, T. A. (2014). Modeling US adult obesity trends: a system dynamics model for estimating energy imbalance gap. American Journal of Public Health, 104(7), 1230-1239. doi:10.2105/AJPH.2014.301882

Farley, T. A., \& Dowell, D. (2014). Preventing Childhood Obesity: What Are We Doing Right?. American Journal of Public Health, 104(9), 1579-1583. doi:10.2105/AJPH.2014.302015.

Finkelstein E., Ruhm C., \& Kosa K. (2005). Economic causes and consequences of obesity. Annual Review of Public Health. 26, 239-257.

Huffman, S., \& Rizov, M. (2007). Determinants of obesity in transition economies: The case of Russia. Economics and Human Biology, 5, 379-391.

Kirby, J. B., Liang, L., Chen, H., \& Wang, Y. (2012). Race, Place, and Obesity: The Complex Relationships Among Community Racial/Ethnic Composition, Individual Race/Ethnicity, and Obesity in the United States. American Journal of Public Health, 102(8), 1572-1578. doi:10.2105/AJPH.2011.300452.

Koenker R. Quantile Regression [e-book]. Cambridge: Cambridge University Press; 2005. Retrieved from: eBook Collection (EBSCOhost), Ipswich, MA. Accessed October 15, 2015.
Li, C., Balluz, L. S., Okoro, C. A., Strine, T. W., Lin, J. S., Town, M., \& Valluru, B. (2011). Surveillance of certain health behaviors and conditions among states and selected local areas -- Behavioral Risk Factor Surveillance System, United States, 2009. Morbidity And Mortality Weekly Report. Surveillance Summaries, 60(9), 1-250.

Lin, B., Huang, C., \& French, S. (2004). Factors associated with women's and children's body mass indices by income status. International Journal of Obesity, 28, 536-542.

Liu, S., Walter, S., Marden, J., Rehkopf, D., Kubzansky, L., Nguyen, T., \& Glymour, M. (2015). Genetic vulnerability to diabetes and obesity: Does education offset the risk?. Social Science \& Medicine, 127(Special Issue: Educational Attainment and Adult Health: Contextualizing Causality), 150-158. doi:10.1016/j.socscimed.2014.09.009.

Ljungvall, A., \& Zimmerman, F. (2012). Bigger bodies: Long-term trends and disparities in obesity and body-mass index among U.S. adults, 1960-2008. Social Science \& Medicine, 75(1), 109119.

Mabry, P. L., \& Bures, R. M. (2014). Systems Science for ObesityRelated Research Questions: An Introduction to the Theme Issue. American Journal of Public Health, 104(7), 1157-1159 3p. doi:10.2105/AJPH.2014.302083.

McLaren, L. (2007). Socioeconomic status and obesity. Epidemiologic Reviews, 29, 29-48.

Nayga, R. (2000). Schooling, health knowledge and obesity. Applied Economics, 32, 815-822.

Ogden, C., Flegal, K., Carroll, M., \& Johnson, C. (2002). Prevalence and trends in overweight among US children and adolescents, 1999-2000. Journal of the American Medical Association, 288, 1728-1732.

Pierannunzi, C., Hu, S. S., \& Balluz, L. (2013). A systematic review of publications assessing reliability and validity of the Behavioral Risk Factor Surveillance System (BRFSS), 20042011. BMC Medical Research Methodology, 13, 49. doi:10.1186/1471-2288-13-49.

Prentice, D. A., \& Miller, D. T. (1992). When small effects are impressive. Psychological Bulletin, 112, 160-164.

U.S. Bureau of Labor Statistics. Food Services and Drinking Paces (2016). Retrieved from http://www.bls.gov/iag/tgs/iag722.htm. Accessed October 25, 2015.

U.S. Department of Health \& Human Services National Heart and Lung Institute. BMI Calculator (2016). Retrieved from http://www.nhlbi.nih.gov/health/educational/lose_wt/BMI/bmic alc.htm. Accessed October 25, 2015.

Yen, S., Chen, Z., Eastwood, D. (2009). Lifestyles, demographics, dietary behaviour, and obesity: A switching regression analysis. Health Services Research, 44, 1345-1369.

Zhang, Q., \& Wang, Y. (2004). Socioeconomic inequality of obesity in the United States: Do gender, age, and ethnicity matter? Social Science \& Medicine, 58(6), 1171-1180. 